\title{
International Journal of \\ IJBESAR Business and Economic Sciences Applied Research \\ ijbesar.ihu.gr
}

\section{Corporate Governance, CEO Compensation and accounting conservatism}

Pakamas Srichoke ${ }^{2}$, Georgios Georgakopoulos ${ }^{3}$, Alexandros Sikalidis ${ }^{1,2,4}$, Athina Sotiropoulou ${ }^{5}$

University of Amsterdam, Amsterdam Business School, Plantage Muidergracht 12, 1018 TV, Netherlands

'Agricultural University of Athens, Iera Odos 75, Athens 118 55, Greece

International Hellenic University, $14^{\text {th }} \mathrm{km}$ Thessaloniki- Nea Moudania 57001, Greece

University of Patras, University Campus, 26504 Rio Achaia, Greece

\begin{tabular}{ll}
\hline ARTICLE INFO & ABSTRACT \\
\hline Article History & Purpose:
\end{tabular}

Received 22 April 2021 ; Accepted 19 July 2021 This study examines the moderating impact of corporate governance quality on the relation JEL Classifications G3, M12, M4 between CEO bonus compensation and accounting conservatism.

Design/methodology/approach:

We use market-based and accrual-based measures to estimate accounting conservatism. According to prior literature (Core, Holthausen and Larcker, 1999; Bhojraj and Sengupta, 2003; Rees and Rodionova, 2015), agency and managerial self-interest theory state that corporate governance strength can mitigate the negative relation between CEO bonus compensation and accounting conservatism.

Finding:

Our sample consists of S\&P 500 companies while our empirical findings suggest that CEO bonus compensation and accounting conservatism are positively associated.

Research limitations/implications:

Thus, our results do not provide clear evidence about the direction of the effect of strong corporate governance. Both measures of accounting conservatism do not give significant relations, therefore the results about corporate governance strength are contradicting. The results hold the same after controlling for industry-specific effects.

Originality/value:

The purpose of this study is to shed light to the literature of accounting conservatism, corporate governance and CEO compensation. Furthermore, this research examines the current situation of corporate governance and motivates future improvement of corporate governance mechanisms.

Keywords:

Corporate Governance,

Executive Compensation,

Accounting and Auditing

\section{Introduction}

The role of corporate governance is very important and it includes the monitoring of managers' behavior and the protection of shareholders' interests to maximize their profit (Bhojray \& Sengupta, 2003; Luo \& Salterio, 2014). Nevertheless, existing literature criticizes the implementation of corporate governance in organizations as the current corporate governance mechanisms lack effectiveness and efficiency (Shleifer \& Vishny, 1997; Luo \& Salterio, 2014). The agency theory states that managers make decisions motivated by their own motives and they do not take into account shareholders' interests due to information asymmetry. We have to examine the effectiveness of strong corporate governance on moderating the incentives that managers have to increase their own wealth (Watts \& Zimmerman, 1978). 
Givoly and Hayn (2000) state that accounting conservatism and financial reporting are increasing over time. Basu (1997) examines conservatism in earnings and his primary goal is to shed light to accounting accruals. His results suggest that the sensitivity of earnings is two to six times higher to negative returns than to positive returns. Prior literature indicates the differences in international level of corporate governance and the association with conservative reporting (e.g. Ball, Kothari \& Robin, 2000).

Prior research also examines the association between corporate ownership structure and the information that earnings provide (Fan \& Wong, 2002). Core et al. (1999) analyze the effect of corporate governance structure on CEO compensation and firm performance. Their results indicate that organizations with weaker corporate governance face greater agency problems, higher levels of CEO compensation and their performance is relatively poor. This study examines the impact of corporate governance strength on the relation between accounting conservatism and CEO compensation. The contribution of this study concerns accounting conservatism, CEO compensation and corporate governance.

Building on existing literature, the agency theory (Jensen \& Meckling, 1976; Bris \& Cantale; 2004) and the managerial selfinterest assumption (Watts \& Zimmerman, 1978; Guth \& MacMillan; 1986), a negative relationship is expected between earnings-based CEO compensation and accounting conservatism. CEOs have motives to over value firm's value to receive a higher bonus due to the fact that their compensation is earnings-based. Overvaluation of net asset or net income has negative impact on firms as it can possibly reduce stock price. The contribution of corporate governance is very important because it can moderate agency problems and reduce agency costs for the organization (Core et al., 1999; Bhojraj \& Sengupta, 2003; Rees \& Rodionova, 2015). Thus, we hypothesize that the stronger the corporate governance strength, the smaller the agency problem. The measure of corporate governance strength is corporate governance pillar scores from the Thomson Reuters ASSET4 ESG. The agency conflict of this study is captured by the negative relation between earnings-based CEO compensation and accounting conservatism.

During the past years financial crisis and scandals of international companies (Enron, WorldCom) resulted to increased attention to corporate governance and CEO compensation. Agrawal and Chadha (2005) examine the relation between corporate governance features and the likelihood of organizational restatement of earnings. Berry, Fields and Wilkens (2006) examine several functions of corporate governance and specifically they focus on the interaction between insider ownership, board composition, organizational compensation structure and unaffiliated block ownership. Prior research indicates that accounting conservatism is increasing through the years (Givoly and Hayn, 2000) while extensive literature examines the factors that have an impact on conservative reporting in accounting (e.g. Watts, 2003; Ball et al., 2000).

The contribution of this study is multiple. First of all, this empirical research contributes to the academic literature as it examines the mitigating impact of corporate governance strength on the relation between earnings-based CEO compensation and accounting conservatism. Second, this study contributes from a societal point of view. We examine the impact of current state of corporate governance on the relation between accounting conservatism and CEO compensation and its implications on future improvement of corporate governance. Corporate governance reform attracted global attention during the previous years (Porta, Lopez-de-Silanes, Shleifer, \& Vishny, 2000). According to Kirkpatrick (2009) financial crisis provides plenty information to analyze the dysfunctions of corporate governance. Financial crisis of 2008 , corporate failures and scandals have changed the financial market significantly. Therefore, the attention on corporate governance mechanisms and corporate governance reform has increased. For this reason, Matsumura and Shin (2005) suggest future research about CEO compensation reform and the related corporate governance reform. Third, from an organizational and shareholder point of view, shareholders may invest more on corporate governance reform in case that the empirical results indicate that the current form of corporate governance has several dysfunctions. The reason why shareholders may invest on corporate governance reform is that they intend to protect their interests and they want higher levels of market performance (Tuschke \& Sanders, 2003). Fourth, from a debtholders perspective, the awareness of low quality corporate governance could lead to very thorough examination of the company before they make an investment decision to avoid 'bad' investment decisions.

Overall, the contribution of this research is the critical evaluation of corporate governance mechanisms and the stimulation of future improvements in the characteristics of corporate governance.

\section{Literature review}

\subsection{Accounting Conservatism}

Prior research indicates the continuous increase of accounting conservatism (Givoly and Hayn, 2000). Managers, investors and accountants prefer measurement errors that are due to understatements rather than overstatements of organization's net asset and net income (FASB Statement of Concepts No.2). In the empirical research there is not a common definition of accounting conservatism. A "classic" definition of the accounting conservatism is; "anticipating no profit, but anticipate all losses" (Bliss, in Watts, 2003, p. 208). FASB in the Statement of Concepts No. 2 defines accounting conservatism as; "a prudent reaction to uncertainty to try to ensure that uncertainty and risk inherent in business situation are adequately considered". The academic literature often uses the following definition for accounting conservatism; "the accountant's tendency to require a higher degree of verification for recognizing good news than bad news in financial statements" (Basu, 1997, p. 4). According to Guay and Verrecchia (2006) accounting conservatism is defined as; "more timely recognition of losses than gains as a result of the costs and benefits of reporting verifiable information by managers and/or firms being asymmetric" (p. 149).

Watts (2003) indicates four explanations for conservatism that are confirmed by Bushman and Piotroski (2006). First, the contracting explanation states that accounting conservatism is used to face moral hazard problems in a company. Information asymmetry, asymmetric pay-offs, limited ability and limited horizon between several parties in the company generate these 
problems. The compensation contract belongs in this type of problems (Watts, 2003). Watts, 2003 indicates that managers are less probable to over value net income and net assets for their own interests.

The litigation explanation is based on the litigation cost that managers face if they over value earnings and assets. Therefore, managers tend to understate net income to avoid high litigation costs. Thirdly, the income tax explanation, focuses on the association between reporting income and taxable income since the higher the reporting income, the higher the taxable income. Accounting conservatism in financial reporting results in reduced income and thus, to lower taxes. According to Watts (2003) the regulation explanation indicates that losses from overvaluation tend to be more noticeable from political processes than gains from underestimation. Therefore, regulators and standard setters tend to make decisions taking into account accounting conservatism. On the other hand, according to Ahmed, Billings, Morton, and Stanford-Harris, (2002) accounting conservatism enables company to reduce debt costs. Furthermore, it has a moderating role in the dividend policy conflict between bondholder and shareholders. Firms that implement accounting conservatism have better cash flows in case that their management makes overconfident decisions (Hsu, Novoselov \& Wang, 2017).

\subsection{CEO Compensation}

There is a lot of controversy concerning relatively high CEO compensation. Specifically, high CEO compensation raises concerns about ethical issues and the accountability of a firm. Regulators, corporate governance and society examine thoroughly CEO compensation. The Sarbanes Oxley Act (SOX) that was implemented in 2002 is an effort to diminish these concerns. The period after the implementation of SOX is characterized by lower incentive compensation and decisions that include risk (Cohen, Dey \& Lys, 2004).

In U.S, the compensation of managers is a result of negotiations with the CEO (Bushman, Indjejikian \& Smith, 1996). The negotiations concern the incentive and the salary of the manager. The incentive that depends on CEO performance has two factors: a bonus that is received on annual basis and a long-term plan. Existing literature suggests that corporate performance and CEO compensation are positively related, and vice versa (Smirnova \& Zavertiaeva, 2017). According to Healy (1985) earnings-based bonus schemes is a very important means of reward for firms' executives. Companies can achieve several goals by using compensation. Compensation mitigates the conflict of interests between shareholders and executive managers (Gillan, 2006). Nevertheless, stock options (equity-based compensation) are often associated with fraud in companies (Denis, Hanouna, \& Sarin, 2006). Furthermore, managers overestimate net income of the company to achieve the annual bonus. Prior research indicates that more powerful CEOs receive higher ex-ante bonus and they achieve greater amount of non-financial performance targets (Bachmann, Loyeung, Matolcsy \& Spiropoulos, 2019).

\subsection{Relation of CEO earnings-based bonus compensation and accounting conservatism}

\subsubsection{Agency Theory}

The agency problem in a company is a result of information asymmetry. Bris and Cantale (2004) indicate the internal and external view of the agency problem. The external view focuses on the different interests of regulators and shareholders. The internal view analyzes the dispute between executives and shareholders. In their research, Larcker and Tayan (2011) present a similar opinion: the stakeholder and shareholder perspective. The stakeholder viewpoint focuses on the social responsibility that the managers, the company and the employees have. The shareholder viewpoint indicates that the main purpose of the firm is the maximization of shareholder's value. In this study we analyze the internal/shareholder perspective of the agency theory.

\subsubsection{Managerial self-interest}

Executive managers make decisions about investments, finance and operations of a company. Furthermore, they have the authorization to select accounting methods (Larcker \& Tayan, 2011). Managers can provide unbiased accounting by reporting the actual performance of the company and in that way they maximize the efficiency of their contract in the company. In contrast, management executives can provide biased accounting by reporting earnings in firm's financial statements that do not capture company's actual performance. Their motive is to maximize their own wealth.

Prior literature indicates that individuals act for their own interests. Managers would lobby for accounting standards based on their own interests (Watts \& Zimmerman, 1978). The results of Guth and MacMillan (1986) focus on the decisions that managers make to sabotage, change, delay or decrease the quality of organization's strategy to maximize their own wealth. The optimal contracting theory is in line with these results as well suggesting that the primary goal of management is not to achieve the maximization of shareholders' value (Bebchuk \& Fried, 2003).

\subsection{Corporate governance}

Media's attention on corporate governance is increased during the past years due to organizations' fraudulent behavior, scandals, outrageously high management compensations and inside trading (Larcker \& Tayan, 2011). The results of these companies' failures are resignation of executives, lawsuits and bankruptcy of the firm. Corporate governance can prevent these events in case that it is implemented effectively. Inadequate corporate governance raises international concerns (Khanchel, 2007). During the past decade events as Enron, WorldCom and Arthur Anderson scandals as well as SOX implementation indicate the significance of corporate governance. 
According to Larcker and Tayan (2011) the responsibility of corporate governance mechanisms are to control managers' behavior, protect shareholders and diminish cost of agency. The amount of the agency costs, the ability for the control mechanism and the implementation cost of control mechanisms define whether a control mechanism is necessary or not.

Better quality of corporate governance results in better market valuation and operating performance (Klapper \& Love, 2004). Effective implementation of corporate governance reduces the risk for investors and provides reasonable return to their investment (Shleifer \& Vishny, 1997). Corporate governance improves the agency problem and has a positive impact on firm value (Renders \& Gaeremynck, 2012).

\section{Hypotheses development}

\subsection{CEO compensation and accounting conservatism}

According to the agency theory CEOs are motivated by their own interests and therefore they make decisions to increase their wealth. CEOs tend to implement accounting practices such as overvaluation of net income and net asset to increase their earnings-based compensation. Shalev, Zhang and Zhang (2013) argue that in case that CEOs compensation is based more on earnings-based bonuses, they tend to over allocate the purchase price to goodwill when an acquisition occurs. Since amortization is not implemented in goodwill the over allocation of goodwill will result to higher post-acquisition earnings and therefore managers will receive higher bonus.

Healy (1985) examines the impact of bonus schemes on the decisions that managers make about accounting policies. Managers are motivated to make certain accounting decisions about firm's policy and accruals to receive higher compensation. Executives use accruals both for the increase of income and for the decrease of income (big bath case) as well (Healy, 1985). The use of income-decreasing accruals indicates that earnings-based component (bonus) in a CEO's compensation and accounting conservatism in financial statements are negatively associated. In contrast, income-increasing accruals indicate lower compensation for the manager. Moreover, managers tend to be less conservative in case that their compensation is mainly earnings - based (Shalev et al., 2013). Thus, they will try to get their bonus target and higher earnings-based compensation. However, literature suggests that in many cases there is positive relation between high CEO compensation and high level of accounting conservatism. Organizations adopt conservative accounting practices to inform adequately the investors and diminish the litigation risk due to recent financial crisis. Furthermore, companies could report conservatively to prevent the overvaluation that will attract government's attention. This is in line with the regulation explanation for accounting conservatism (Watts, 2003). Managers often ignore the litigation and regulation risk while they tend to make riskier decisions than other individuals in an organization (Kamalanabhan \& Sunder, 1999). Making decisions that include risk is considered an important component of managerial behavior (Kamalanabhan \& Sunder, 1999). March and Shapira (1987) argue that there are three conditions that encourage managers to make riskier decisions and one of them is concerns the achievement of specific performance targets. According to Rappaport (2005), managers focus on earnings in the short-term. Hence, they make decisions that increase short-term earnings based on their own interests or they aim to over value earnings in order to achieve higher short-term bonus (Watts \& Zimmerman, 1978; Guth \& MacMillan, 1986). According to the managerial self-interest theory (Watts \& Zimmerman, 1978; Guth \& MacMillan, 1986), managerial risky decisions (Kamalanabhan \& Sunders, 1999; March \& Shapira, 1987) and their focus on short-term earnings (Rappaport, 2005) suggest a negative relation between earnings-based CEO compensation and accounting conservatism. Therefore, we form the first hypothesis:

$H_{1}$ : Earnings-based component in a manager's compensation is negatively related with accounting conservatism.

This phenomenon can be characterized as the agency problem. Prior literature examines CEOs compensation as a means to diminish agency problems (Bebchuk \& Fried, 2003). The decision of executives to over value net income and net asset to achieve their target bonus and as a result to maximize their own wealth is in conflict with the interest of shareholders. Intentional or unintentional disclosure of overvaluation information reduces firm's share price. Therefore, it is expected to have a negative impact on the company value and shareholders.

\subsection{Corporate governance and agency theory}

Financial statements inform investors about firm's performance and they have a strong impact on investors' asset allocation decisions. Consequently, manager's performance and its disclosure in financial statements affect their compensation. Therefore, CEOs have the incentive to manipulate accounting numbers in financial disclosures and this leads to significant agency costs. Agency problems could be diminished with the implementation of strong corporate governance. Core et al. (1999) argue that organizations with weaker corporate governance tend to deal with agency problems. They also indicate that in companies with high manager's compensation, greater agency problems occur. Bhojraj and Sengupta (2003) find that corporate governance reduces agency costs, monitors managerial behavior and solves information asymmetry problem between the organization and lenders. Thus, company's default risk is reduced. According to Rees and Rodionova (2015) effective corporate governance mechanisms protect stakeholders' interests by mitigating agency problems and decreasing extremely high CEOs compensations. Bebchuk and Fried (2003) argue that executives receive higher compensation when CEOs are more powerful than the corporate board.

Prior research indicates that effective corporate governance is able to reduce agency problems and subsequent costs. Therefore, stronger corporate governance can mitigate the negative relation between earnings-based CEO compensation and accounting conservatism. Corporate governance strength is expected to reduce the impact of executives' compensation on 
accounting conservatism. The moderating impact of corporate governance strength is positively associated with accounting conservatism. Therefore, we form the second hypothesis:

$H_{2:}$ The negative relationship between earnings-based managers' compensation and accounting conservatism is expected to be less pronounced at the presence of a high level of corporate governance.

Stronger corporate governance mechanisms are more effective to mitigate organizations' agency problems (Bhojraj \& Sengupta, 2003; Rees \& Rodionova, 2015; Leventis, Dimitropoulos \& Owusu-Ansah, 2013). The stronger the corporate governance mechanisms, the stronger the mitigating impact on the negative effect of CEOs earnings-based compensation on accounting conservatism. Thus, accounting conservatism increases due to the reduction of the impact of earnings-based component in a CEO's compensation on conservatism.

\section{Methodology and data selection}

\subsection{Data selection}

Archival research is used to investigate the research question and hypotheses. We use several databases to collect the data. We derive data about earnings-based CEO compensation (bonus) from ExecuComp. Compustat and Datastream databases are used to obtain data concerning accounting conservatism. Corporate governance data are extracted from ASSET4 ESG. Database research is the most appropriate methodology for this study due to the adequacy of data. The use of secondary data is very time-consuming concerning data analysis and interpretation (Saunders, Lewis \& Thornhill, 2009).

The sample consists of U.S companies (S\&P 500) during the years 2008 to 2013. This study examines years 2008 to 2013 to investigate the impact of the current form of corporate governance on the agency problem. The financial crisis of 2008 has attracted significant attention to the implementation of corporate governance and executive remuneration systems. The financial crisis enables the researchers to investigate the weaknesses and inefficiencies of corporate governance. This is the reason why the sample includes the year 2008 .

Table 1. Sample mutations

\begin{tabular}{lc}
\hline & Firm years \\
\hline Collected firm years & 3000 \\
After deleting missing values of corporate governance data & 2863 \\
After merging with financial data & 2045 \\
After merging with CEO compensation data & 1865 \\
After deleting financial institutions & 1717 \\
\hline Total firm years for sample & 1717 \\
\hline
\end{tabular}

Table 1 presents the firm-years that are included in the sample which consists of 1717 firm year observations. Table 2 provides an overview of the industry distribution of the sample. The majority of the firms are in manufacturing followed by transportation and public utilities while the smallest amount of observations of our sample is in the mining and construction industry.

Table 2. Observations per industry

\begin{tabular}{lccc}
\hline Industry & SIC & Observations & $\%$ \\
\hline Mining and Construction & $1000-1999$ & 94 & $5.5 \%$ \\
Manufacturing & $2000-3999$ & 896 & $52.2 \%$ \\
Transportation and Public Utilities & $4000-4999$ & 277 & $16.1 \%$ \\
Wholesale Trade and Retail Trade & $5000-5999$ & 211 & $12.3 \%$ \\
Services & $7000-8999$ & 239 & $13.9 \%$ \\
\hline Total observations & & 1717 & $100 \%$ \\
\hline
\end{tabular}

\subsection{Empirical design}

According to literature the most common measure for accounting conservatism are: the accrual-based measure (Ahmed et al., 2002; Givoly \& Hayn, 2000; Ball \& Shivakumar, 2005) and market-based measure (Ahmed et al., 2002; Beaver \& Ryan, 2000). In this study both the accrual-based measure and the market-based measure are used to enhance the credibility of the research. The accrual-based proxy of conservatism is $C O N-A C C$. Prior literature is used to construct the measure (Givoly \& Hayn, 2000; Ahmed et al., 2002). They suggest the sign and magnitude of accumulated accruals during a period of time as a proxy for accounting conservatism. Unbiased accounting procedures tend to result in net accumulative accruals with a value equal approximately to zero in the long term period. Conservatism in accounting introduces bias and therefore different 
acknowledgment of gains and losses occurs. Givoly and Hayn (2000) argue that this results in persistence of negative accruals over time. Cash flows from operations exceed organization's net income. Consequently, the magnitude of negative accruals is associated with the level of accounting conservatism. Bissessur (2008) associates asymmetric recognition of gains and losses with asymmetric accruals due to the fact that future losses are completely accrued. On the contrary future profits have a higher level of recognition.

We estimate $C O N-A C C$ based on Ahmed et al. (2002) as following: net income before extraordinary items plus depreciation expense minus cash flows from operations deflated by average total assets. The proxy is multiplied by -1 to achieve simultaneous increase of conservatism and negative accruals. Positive $C O N-A C C$ indicates accounting conservatism. The relation between $C O N-A C C$ and accounting conservatism is positive.

The market-based proxy of conservatism is $C O N-B T M$ (book value divided by the market value of the company multiplied by -1). The book-to-market ratio contains bias in accounting recognition and lagged accounting recognition (Beaver \& Ryan, 2000). Conservative accounting results to difference between the book and market value in the biased accounting component of the ratio (Ahmed et al., 2002). Market value is consistently higher than book value due to conservatism (Beaver \& Ryan, 2000). $C O N-B T M$ is the book value of the company divided by the market value and then multiplied by -1 (Ahmed et al., 2002). Thus, the higher the accounting conservatism is, the higher the value of the proxy is expected.

In this study we use as an independent variable the earnings-based CEO compensation, BONUS. This variable is measured by the bonus intensity of the compensation and it is estimated by dividing the ratio of bonus components by the total CEO compensation. Managers tend to disclose higher degree of earnings to receive higher bonus. Thus, when the BONUS proxy increases, the accounting conservatism is expected to decrease.

Rating and ranking companies have a significant impact on consumer, sell-side analysts and investors' behavior (Ioannou \& Serafeim, 2010). Investors rely on information provided by independent companies concerning corporate governance of organizations. Corporate governance scores have a significant impact on stakeholders' perspectives about corporate governance strength and performance. To measure corporate governance strength we use corporate governance scores from Thomson Reuters ASSET4 ESG through Datastream. The moderating variable corporate governance strength is referred to as CGSTRENGTH. Data for more than 4000 international companies are available since 2002. These data contain environmental, social and governance (ESG) information for the companies. ESG criteria are used to rank companies by ASSET4 and are normalized using z-score into $0 \%-100 \%$ interval, which provides more than 1000 data items. In this study, we use the overall score concerning the pillar of corporate governance where the higher the ASSET4 values, the stronger the corporate governance strength of firms.

In this study we include several variables that can influence the relation between CEO compensation and accounting conservatism as control variables. First, we use organization's size (SIZE: the natural log of firm's total assets). Larger firms provide more and better quality of information. Therefore, information asymmetry is relatively lower and accounting conservatism is not that necessary (Khan \& Watts, 2009). However, litigation risks are higher for larger companies thus the demand for conservative accounting is increased (Khan \& Watts, 2009). According to prior research of Zmijewski and Hagerman (1981) organizations' size has an impact on their accounting strategies. Sanders and Carpenter (1998) argue that size of the firm and CEO compensation are associated. Secondly, we use growth of sales (SALESGROWTH: the percentage of annual change of firm sales) as control variable. Agency costs and growth options are expected to have a positive relationship (Smith \& Watts, In Khan \& Watts, 2009). Higher sales growth indicates higher level of accounting conservatism. Prior research states that sales growth influences firm's accruals and future growth of market and this affects the conservatism measure of firm's market-to-book ratio. Murphy (1985) argues that CEO compensation has a positive association with company's performance measured by sales growth. Thirdly, leverage ( $L E V$ : long-term debt over total assets) is used as control variable. Leverage and conflicts of shareholders and debtholders interests are positively associated due to their asymmetric risk appetite (Watts, 2003). Moreover, leverage and director cash compensation are expected to be positively related (Brick, Palmon \& Wald, 2006). A fourth control variable is return on assets $(R O A)$ based on prior research of Ahmed et al. (2002). ROA is used to control for conservatism costs. Firms with high level of profits can afford conservative accounting more easily than firms that are not so profitable. Thus, firms with higher ROA tend to make more conservative disclosures. The last control variable that we use is litigation risk (LITIGATIONRISK). Companies are expected to adopt accounting conservatism in case that they face higher litigation risk and thus, higher litigation costs (Watts, 2003). We create a dummy variable for organizations with high litigation risk. Prior research indicates that firms with the following SIC codes: 2833-2836, 3570-3577, 7370-7374, 36003674, and 5200-5961 have high litigation risk (Francis, Hasan, Park \& Wu, 2009). According to Francis et al. (2009) an appropriate measure of litigation risk is whether an industry had plenty litigation incidences during the prior years.

\subsection{Hypothesis testing}

We use the following model to investigate the impact of CEO bonus compensation on accounting conservatism $\left(\mathrm{H}_{1}\right)$ : CON-ACC ${ }_{\mathrm{i}} /$ CON-BTM $_{\mathrm{i}}=\alpha_{0}+\alpha_{1}$ BONUS $_{\mathrm{i}}+\alpha_{2}$ SIZE $_{\mathrm{i}}+\alpha_{3}$ SALESGROWTH $_{\mathrm{i}}+\alpha_{4} \mathrm{LEV}_{\mathrm{i}}+\alpha_{5}$ ROA $_{\mathrm{i}}+\alpha_{6}$ LITIGATIONRISK $_{\mathrm{i}}$ $+\varepsilon_{\mathrm{i}}$

We use the following model to examine the mitigating effect of corporate governance strength on the association between $\mathrm{CEO}$ bonus compensation and accounting conservatism $\left(\mathrm{H}_{2}\right)$ :

$\mathrm{CON}-A C C_{\mathrm{i}} /{\mathrm{CON}-\mathrm{BTM}_{\mathrm{i}}}=\alpha_{0}+\alpha_{1}$ BONUS $_{\mathrm{i}}+\alpha_{2}$ BONUS $_{\mathrm{i}} * \mathrm{CGSTRENGTH}_{\mathrm{i}}+\alpha_{3} \mathrm{CGSTRENGTH}_{\mathrm{i}}+\alpha_{4} \mathrm{SIZE}_{\mathrm{i}}+$ $\alpha_{5}$ SALESGROWTH $_{\mathrm{i}}+\alpha_{6}$ LEV $_{\mathrm{i}}+\alpha_{7}$ ROA $_{\mathrm{i}}+\alpha_{8}$ LITIGATIONRISK $_{\mathrm{i}}+\varepsilon_{\mathrm{i}}$ 
CEO compensation and accounting conservatism are negatively related in case that the coefficient of BONUS ( $\left.\alpha_{1}\right)$ is negative. The first hypothesis is not rejected if the results are significant. The relation between CEO bonus compensation and accounting conservatism is relatively small when corporate governance strength takes high values in case that the coefficient for the interaction term BONUS*CGSTRENGTH $\left(\alpha_{2}\right)$ is positive. This result would indicate that accounting conservatism and corporate governance strength are positively related. If the results are significant the second hypothesis is not rejected.

\section{Empirical analysis}

\subsection{Descriptive statistics}

Table 3 shows the descriptive statistics of all the variables of our sample.

The value of mean for the variable $C O N-A C C$ that measures accounting conservatism is positive (.022). This is in line with the literature (Ahmed et al., 2002). A positive mean value of $C O N$ - $A C C$ indicates accounting conservatism.

The value of mean of $C O N-B T M$ is negative (-.399) which also indicates accounting conservatism. Therefore, both variables that measure accounting conservatism provide evidence for conservatism in the sample.

Table 3. Descriptive Statistics

\begin{tabular}{|c|c|c|c|c|c|}
\hline Variable & Mean & Median & Std. Dev. & Minimum & Maximum \\
\hline CON-ACC* & 0.022 & 0.017 & 0.047 & -0.096 & 0.246 \\
\hline CON-BTM* & -0.399 & -0.345 & 0.274 & -1.363 & 0.180 \\
\hline BONUS & 0.024 & 0.000 & 0.074 & 0.000 & 0.440 \\
\hline CGSTRENGTH & 79.210 & 82.690 & 13.888 & 27.860 & 96.080 \\
\hline SIZE & 23.160 & 23.039 & 1.141 & 20.960 & 26.250 \\
\hline SALESGROWTH & 0.074 & 0.060 & 0.016 & -0.357 & 0.675 \\
\hline LEV & 0.226 & 0.212 & 0.154 & 0.000 & 0.750 \\
\hline $\mathrm{ROA}$ & 0.076 & 0.070 & 0.068 & -0.167 & 0.284 \\
\hline LITIGATIONRISK & 0.260 & 0.000 & 0.441 & 0.000 & 1.000 \\
\hline
\end{tabular}

*: numbers adjusted by the “-1" factor

The value of the average bonus component related to total CEO compensation is relatively low (2.4\%). This could be due to the fact that for many years CEO compensation was zero, and this resulted to a decrease of the average rate in the sample. The average corporate governance strength is 79.210 estimated in a scale from $0-100$. Corporate governance mechanisms in the companies of the sample are strong. The average annual sales growth is approximately 7.4 percent and the average return on assets is 7.6 percent. 26 percent of the companies of the sample have high litigation risk.

\subsection{Pearson Correlation Matrix}

We use Pearson correlation matrix to check for multicollinearity in the data. Correlations greater than .9 are multicollinearity indicators (Field, 2000). Table 4 presents the 2-tailed Pearson correlation matrix of the variables. The results in Table 4 suggest that there is no multicollinearity in our sample as all correlation values are below .9.

There is a negative correlation between $C O N-A C C$ and $C O N-B T M$, however the relation is not significant. There is a positive correlation between the independent variable $B O N U S$ and $C O N-A C C$. BONUS and $C O N-B T M$ are negatively correlated and their relation is significant in 0.01 level. There is a negative relation between $C G S T R E N G T H$ and $C O N-A C C$ which is significant at the 0.01 level. Furthermore, CGSTRENGTH is negatively related with $C O N-B T M$ (significant at 0.05 level) and BONUS, as we expected (significant at 0.01 level). The negative correlation between CGSTRENGTH and both conservatism measures $(C O N-A C C$ and $C O N-B T M)$ is not line with expectations. According to literature strong corporate governance mechanisms result in conservative accounting methods, however the results of correlation matrix contradict prior research. There is a negative correlation between BONUS*CGSTRENGTH and conservatism measures. However, the relations are not significant. On the contrary, LITIGATIONRISK is positively correlated with $C O N-A C C$ and $C O N-B T M$ (significant at the 0.01 level). This result is in line with prior literature suggesting that organizations with high litigation risk tend to report more conservative. 
Table 4. Correlation matrix between dependent, independent and control variables

\begin{tabular}{|c|c|c|c|c|c|c|c|c|c|c|}
\hline Variable & $\mathrm{CON}-\mathrm{ACC}$ & CON-BTM & BONUS & CGSTRENGTH & $\begin{array}{c}\text { BONUS* } \\
\text { CGSTRENGTH }\end{array}$ & SIZE & $\begin{array}{c}\text { SALES } \\
\text { GROWTH }\end{array}$ & $\mathrm{LEV}$ & $\mathrm{ROA}$ & $\begin{array}{c}\text { LITIGATION- } \\
\text { RISK }\end{array}$ \\
\hline $\mathrm{CON}-\mathrm{ACC}$ & 1.000 & & & & & & & & & \\
\hline \multirow{2}{*}{ CON-BTM } & -0.020 & 1.000 & & & & & & & & \\
\hline & 0.410 & & & & & & & & & \\
\hline \multirow[t]{3}{*}{ BONUS } & $0.050^{* *}$ & $-0.067 * * *$ & 1.000 & & & & & & & \\
\hline & 0.039 & 0.006 & & & & & & & & \\
\hline & & & - & & & & & & & \\
\hline \multirow[t]{2}{*}{ STRENGTH } & $-0.066^{* * *}$ & $-0.050^{* *}$ & $\begin{array}{c}0.066^{* *} \\
*\end{array}$ & 1.000 & & & & & & \\
\hline & 0.006 & 0.039 & 0.006 & & & & & & & \\
\hline \multicolumn{11}{|l|}{ BONUS* } \\
\hline \multirow{2}{*}{$\begin{array}{l}\text { CGSTRENG } \\
\text { TH }\end{array}$} & -0.038 & -0.011 & $\begin{array}{c}0.099^{* * *} \\
*\end{array}$ & $0.153^{* * *} *$ & 1.000 & & & & & \\
\hline & 0.112 & 0.660 & 0.000 & 0.000 & & & & & & \\
\hline \multirow[t]{2}{*}{ SIZE } & $-0.056^{* *}$ & $-0.277 * * *$ & $\begin{array}{c}0.106^{* * *} \\
*\end{array}$ & $0.305^{* * *}$ & $0.104^{* * *}$ & 1.000 & & & & \\
\hline & 0.021 & 0.000 & 0.000 & 0.000 & 0.000 & & & & & \\
\hline \multirow[t]{2}{*}{$\begin{array}{l}\text { SALES } \\
\text { GROWTH }\end{array}$} & $-0.117^{* * *}$ & $0.069^{* * *} *$ & -0.013 & $-0.172^{* * * *}$ & 0.018 & $\begin{array}{c}- \\
0.077 * \\
* *\end{array}$ & 1.000 & & & \\
\hline & 0.000 & 0.004 & 0.599 & 0.000 & 0.462 & 0.001 & & & & \\
\hline \multirow[t]{2}{*}{ LEV } & 0.034 & $0.095^{* * *} *$ & 0.000 & $-0.075^{* * * *}$ & $-0.048^{* *}$ & $\begin{array}{l}0.111^{*} \\
\text { *** }\end{array}$ & $-0.148^{* * *}$ & 1.000 & & \\
\hline & 0.154 & 0.000 & 0.986 & 0.002 & 0.046 & 0.000 & 0.000 & & & \\
\hline \multirow[t]{2}{*}{$\mathrm{ROA}$} & $-0.415^{* * *}$ & $0.463^{*} * *$ & $\begin{array}{c}- \\
0.054^{*} *\end{array}$ & $-060^{* *}$ & $0.057^{* *}$ & $\begin{array}{c}- \\
0.281 * \\
* *\end{array}$ & $0.225^{* * * *}$ & $\begin{array}{c}- \\
0.249^{*} \\
* *\end{array}$ & 1.000 & \\
\hline & 0.000 & 0.000 & 0.025 & 0.012 & 0.018 & 0.000 & 0.000 & 0.000 & & \\
\hline \multirow[t]{2}{*}{$\begin{array}{l}\text { LITIGATIO } \\
\text { N-RISK }\end{array}$} & $0.123^{* * *} *$ & $0.113^{* * *} *$ & -0.016 & 0.034 & 0.042 & $\begin{array}{c}- \\
0.049 * \\
*\end{array}$ & $0.101^{* * * *}$ & $\begin{array}{c}- \\
0228^{*} * \\
*\end{array}$ & $\begin{array}{c}0.150^{*} \\
* *\end{array}$ & 1.000 \\
\hline & 0.000 & 0.000 & 0.508 & 0.162 & 0.085 & 0.041 & 0.000 & 0.000 & 0.000 & \\
\hline
\end{tabular}

$/$ ****** Significant at $0.10 / 0.05 / 0.01$ level 


\subsection{Regression analysis}

\subsubsection{Accounting conservatism and CEO bonus compensation}

First hypothesis examines the relation between $\mathrm{CEO}$ bonus compensation and accounting conservatism measured with two methods: accrual-based method $(C O N-A C C)$ and market-based measure (CON-BTM).

Table 5 presents the results of linear regression between accounting conservatism using the accrual-based measure and managers' bonus compensation.

We perform two multiple linear regressions presented as model I and model II. Model I performs regression only with the control variables while model II contains also the independent variable BONUS.

Table 5. Regression of the accounting conservatism measure CON-ACC on CEO bonus compensation

\begin{tabular}{|c|c|c|c|c|c|c|c|}
\hline & \multirow[t]{2}{*}{ Expectations } & \multicolumn{3}{|c|}{ Model I } & \multicolumn{3}{|c|}{ Model II } \\
\hline & & $\mathbf{B}$ & Beta & Sig. & B & Beta & Sig. \\
\hline Intercept & $?$ & 0.222 & & $(0.000)^{* * * *}$ & 0.227 & & $(0.000)^{* * *}$ \\
\hline BONUS & $(-)$ & & & & 0.002 & 0.046 & $(0.031)^{* *}$ \\
\hline \multicolumn{8}{|l|}{ Control variables } \\
\hline SIZE & $(+/-)$ & -0.008 & -0.184 & $(0.000)^{* * *}$ & -0.008 & -0.189 & $(0.000)^{* * *}$ \\
\hline SALESGROWTH & $(+)$ & 0.000 & -0.043 & $(0.047)^{* *}$ & 0.000 & -0.043 & $(0.046)^{* *}$ \\
\hline LEV & ? & -0.010 & -0.032 & $(0.150)$ & -0.010 & -0.031 & $(0.162)$ \\
\hline $\mathrm{ROA}$ & $(+)$ & -0.344 & -0.492 & $(0.000)^{* * *}$ & -0.343 & -0.491 & $(0.000)^{* * *}$ \\
\hline LITIGATIONRISK & $(+)$ & 0.020 & 0.184 & $\mathrm{O}(.000)^{* * * *}$ & 0.020 & 0.185 & $(0.000)^{* * *}$ \\
\hline $\mathrm{R}^{2}$ & & \multicolumn{3}{|c|}{0.241} & \multicolumn{3}{|c|}{0.243} \\
\hline
\end{tabular}

*/**/*** Significant at 0.10/0.05/0.01 level

In model I $\mathrm{R}^{2}$ is .241 which means that control variables can explain $24 \%$ of the variance of the dependent variable $(C O N-A C C)$. In model II we include the independent variable BONUS resulting in a slightly improved $\mathrm{R}^{2}$ (.243). Model II has a stronger relation to the accrual-based measure for conservative accounting than model I.

The unstandardized coefficient $(\beta)$ of BONUS is positive and significant at the 0.05 level. This indicates that an increase in CEO bonus compensation will result in a small increase in accounting conservatism. This result is not in line with prior literature. Moreover, there is a negative relation between firm's size (SIZE) and accounting conservatism which is significant at the level 0.01. Therefore, an increase in firm's size will lead to a decrease in conservative reporting. Prior research also suggests that larger firms have higher quality of information environment with small degree of information asymmetry and as a result it is not necessary to implement conservative accounting to improve the information that they provide (Khan $\&$ Watts, 2009). In both models the relation between leverage and accounting conservatism is negative but not significant. Prior literature does not provide clear indications for the direction of the relationship between leverage and accounting conservatism. In both model I and model II the unstandardized coefficients for $R O A$ are negative and significant at 0.01 level indicating that an increase in ROA results in a decrease of the level of accounting conservatism. This is not in line with prior literature (Ahmed et al., 2002) that argues that more profitable firms can afford the costs of the implementation of conservative accounting. In both models coefficients of LITIGATIONRISK are positive and significant at 0.01 level. This is in line with prior findings that indicate a positive relation between litigation risk and conservative accounting. Finally, in both models SALESGROWTH has a positive and significant relation with accounting conservatism. Comparing the standardized coefficients $(\beta)$ of the independent variables with a significant relation it could be stated the $R O A(\beta=-.491)$ has the strongest influence and SALESGROWTH $(\beta=-.043)$ has the weakest influence on $C O N-A C C$. To summarize, regression results do not support the first hypothesis as the relation between accounting conservatism (measured by accrual-based method) and CEO bonus compensation is positive and that contradicts our expectations.

We perform a second test to examine hypothesis 1 using the market-based measure CON-BTM for accounting conservatism. The results of the linear regressions are presented in table 6 . We also implement two models, the first one contains only the control variables while the second contains the independent variable BONUS as well. 
Table 6. Regression of the accounting conservatism measure CON-BTM on CEO bonus compensation

\begin{tabular}{lccccccc}
\hline & Expectations & \multicolumn{3}{c}{ Model I } & & \multicolumn{2}{c}{ Model II } \\
\hline Intercept & & B & Beta & Sig. & B & Beta & Sig. \\
BONUS & ? & 0.291 & & $(0.015)^{* *}$ & 0.227 & & $(0.021)^{* *}$ \\
Control variables & $(-)$ & & & & -0.006 & -0.022 & $(0.270)$ \\
SIZE & & & & & & & \\
SALESGROWTH & $(+/-)$ & -0.041 & -0.170 & $(0.000)^{* * *}$ & -0.040 & -0.168 & $(0.000)^{* * *}$ \\
LEV & $(+)$ & 0.000 & -0.022 & $(0.289)$ & 0.000 & -0.022 & $(0.289)$ \\
ROA & $?$ & 0.443 & 0.248 & $(0.000)^{* * *}$ & 0.442 & 0.248 & $(0.000)^{* * *}$ \\
LITIGATIONRISK & $(+)$ & 1.898 & 0.468 & $(0.000)^{* * *}$ & 1.895 & 0.467 & $(0.000)^{* * *}$ \\
\hline R $^{2}$ & $(+)$ & 0.058 & 0.093 & $0(.000)^{* * *}$ & 0.058 & 0.093 & $(0.000)^{* * *}$ \\
\hline
\end{tabular}

*/**/*** Significant at 0.10/0.05/0.01 level

In model I $\mathrm{R}^{2}$ is .296 which means that control variables can explain $29.6 \%$ of the variance of the dependent variable $(C O N-$ $B T M$ ). In model II we include the independent variable BONUS resulting in a relatively small increase in $\mathrm{R}^{2}(.297)$ that does not indicate a significant improvement. However, comparing the results of this regression with the regression that we used the accrual-based measure of accounting conservatism we notice an improvement of $\mathrm{R}^{2}$ of $24 \%$. The model using the market-based measure of conservatism has a better fitting line (goodness-of-fit) with the dataset than the model with the accrual-based measure.

The relation between CEO bonus compensation and accounting conservatism is negative but not significant. The coefficient of SIZE is negative and significant at 0.01 level indicating that larger firms demand lower levels of accounting conservatism. This is in line with prior literature. The relation between litigation risk and market-based measure of accounting conservatism is positive and significant as expected. The regression results for coefficients of SIZE and LITIGATIONRISK with the marketbased measure of conservatism are in line with the regression results with these control variables with the accrual-based measure of conservatism. However, the coefficients of SIZE and LITIGATIONRISK are much larger when they are regressed with the market-based measure suggesting the greater impact of these control variables on market-based measure of conservatism in comparison with the accrual-based measure.

We find a positive and significant relation between accounting conservatism and both ROA as well as leverage of the firm. These results are not in line with the regression results with the accrual-based measure. The positive relation between leverage and accounting conservatism can be explained by the fact that when the leverage of a firm is increased this results to increased risk. As a result, managers decide to increase conservatism to avoid potential damages in case of an economic turndown. The positive relation between ROA and accounting conservatism is in line with the literature. Comparing the strength of the independent variables based on the significant standardized coefficients $(\beta)$, it could be stated that $R O A$ ( $\beta=.467)$ has the strongest impact and LITIGATIONRISK $(\beta=.093)$ the weakest impact on CON-BTM.

To summarize, regression results do not support the first hypothesis as the relation between BONUS and conservatism is not significant. Regressions with market-based measure for accounting conservatism have a better fitting line with the dataset compared to the regressions with accrual-based measure for accounting conservatism. However, both regressions fail to provide evidence that there is a negative relation between conservative accounting and CEO bonus compensation. Using the accrual-based measure results in a positive relation between bonus and conservatism while using the market-based measure results in a negative however not significant relation. Therefore, we reject the first hypothesis.

\subsubsection{The effect of corporate governance strength on the association between CEO bonus and accounting conservatism}

To examine hypothesis 2 , we use both conservatism measures, the accrual-based measure and the market-based measure. First, we conduct three multiple linear regressions by using the accrual-based measure. Table 7 reports the results of the three models. Model I contains the control variables. Model II uses the independent variables BONUS and CGSTRENGTH and model III contains also the moderating variable BONUS*CGSTRENGTH. The variable BONUS*CGSTRENGTH is the interaction term of centered variables BONUS and CGSTRENGTH. We intend to decrease multicollinearity and improve interpretation of the results by centering the variables. $\mathrm{R}^{2}$ is .241 for the first model and .246 for the second and the third model. This indicates that in the first model around 24 percent of the variance of the dependent variable is explained by our model. Including independent variables and the moderating variable in model 2 and 3 improves slightly the results and increases the goodness-of-fit.

Model II and model III have similar results, therefore we focus on model three that contains the moderating variable. The unstandardized coefficient of BONUS is positive and significant at 0.10 level. This is in line with the result of table 5 , which 
indicates that an increase in CEO bonus will increase accounting conservatism. However, this result contradicts prior literature. Corporate governance strength (CGSTRENGTH) has a negative and significant relationship (0.01 level) with conservatism. The moderating variable BONUS*CGSTRENGTH has not a significant relation with the dependent variable. The results of control variables do not differ from these of the analysis of the first hypothesis. However, there is a change in the leverage variable. In table 5 the relation between leverage and accounting conservatism is not significant. In table 7 model III indicates that when we include the moderating variable in the regression, the relation between leverage and conservatism is negative and significant at 0.10 level. Among the independent variables with significant relation, ROA has the strongest influence on accounting conservatism $(\beta=-.490)$ and leverage has the weakest influence on accounting conservatism $(\beta=-.038)$. Overall, our regression results do not support hypothesis 2. Moderating variable (BONUS*CGSTRENGTH) and accounting conservatism are positively related, as expected, however their relation is not significant.

Table 7. Regression of the moderating variable CGSTRENGTH on CON-ACC and CEO bonus compensation

\begin{tabular}{|c|c|c|c|c|c|c|c|c|c|c|}
\hline & \multicolumn{2}{|c|}{ Expectations } & \multicolumn{2}{|c|}{ Model I } & \multicolumn{3}{|c|}{ Model II } & \multicolumn{3}{|c|}{ Model III } \\
\hline & & $\mathrm{B}$ & Beta & Sig. & $\mathrm{B}$ & Beta & Sig. & $\bar{B}$ & Beta & Sig. \\
\hline Intercept & $?$ & 0.222 & & $(0.000)^{* * * *}$ & 0.209 & & $(0.000)^{* * * *}$ & & 0.210 & $(0.000)^{* * * *}$ \\
\hline BONUS & $(-)$ & & & & 0.002 & 0.040 & $(0.061)^{*}$ & 0.002 & 0.041 & $(0.055)^{*}$ \\
\hline CGSTRENGTH & $(+)$ & & & & 0.003 & -0.060 & $(0.009)^{* * * *}$ & 0.003 & -0.061 & $(0.008)^{* * * *}$ \\
\hline $\begin{array}{l}\text { BONUS* } \\
\text { CGSTRENGTH }\end{array}$ & $(+)$ & & & & & & & 0.000 & 0.012 & $(0.573)$ \\
\hline \multicolumn{11}{|l|}{ Control variables } \\
\hline SIZE & $(+/-)$ & -0.008 & -0.184 & $(0.000)^{* * * *}$ & -0.007 & -0.170 & $(0.000)^{* * * *}$ & -0.007 & -0.171 & $(0.000)^{* * * *}$ \\
\hline SALESGROWTH & $(+)$ & 0.000 & -0.043 & $(0.047)^{* * *}$ & 0.000 & -0.054 & (0.289) & 0.000 & -0.054 & $(0.014)$ \\
\hline LEV & $?$ & -0.010 & -0.032 & $(0.000)^{* * * *}$ & -0.012 & -0.038 & $(0.000)^{* * * *}$ & -0.012 & -0.038 & $(0.089)^{*}$ \\
\hline ROA & $(+)$ & -0.344 & -0.492 & $(0.000)^{* * * *}$ & -0.341 & -0.489 & $(0.000)^{* * * *}$ & -0.342 & -0.490 & $(0.000)^{* * *}$ \\
\hline LITIGATIONRISK & $(+)$ & 0.020 & 0.184 & $(0.000)^{* * * *}$ & 0.020 & 0.187 & $(0.000)^{* * * *}$ & 0.020 & 0.187 & $(0.000)^{* * * *}$ \\
\hline $\mathrm{R}^{2}$ & & & \multicolumn{2}{|c|}{0.241} & \multicolumn{3}{|c|}{0.246} & \multicolumn{3}{|c|}{0.246} \\
\hline
\end{tabular}

*/**/*** Significant at $0.10 / 0.05 / 0.01$ level

We conduct a second test for the second hypothesis using as measure of accounting conservatism the market-based measure $(C O N-B T M)$. Again, we run three multiple linear regressions and the results are presented in models I, II, III in table 8. Model I includes the control variables, model II includes the independent variables and model III contains also the moderating variable BONUS*CGSTRENGTH. $\mathrm{R}^{2}$ has similar values in the three models $(296, .299$ and .299) which implies that approximately 30 percent of the variance of the dependent variable is explained by the statistical model. $\mathrm{R}^{2}$ is improved in models II and III indicating better fit of the model in the dataset when including the independent variables and the moderating variable. BONUS and $C O N-B T M$ are negatively related as we expected $(\beta=-.005)$ however their relation is not significant. Corporate governance strength is positively related with conservatism $(\beta=.013)$ and their relation is significant at 0.05 level. Therefore, the results of regression using the market-based measure of accounting conservatism are in line with expectations indicating that an increase in corporate governance strength increases accounting conservatism. There is a negative relation between the moderating variable BONUS*CGSTRENGTH and accounting conservatism ( $\beta=-.004)$ which is not significant. The control variables $L E V$, $R O A$ and LITIGATIONRISK have a positive relation with $C O N-B T M$ at 0.01 significance level. Higher values of leverage, ROA and litigation risk result in higher degree of conservatism as we expected. Size of the company has a negative relation with conservatism $(\beta=-.043)$ at a significant level at 0.01 . As a result, larger firms implement lower levels of accounting conservatism. This is in line with what we expected. SALESGROWTH has not a significant relation with the dependent variable. With respect to the strength of the independent variables with a significant relation, ROA has the strongest impact on $C O N-B T M(\beta=.468)$ and $C G S T R E N G T H$ has the weakest impact on $C O N-B T M(\beta=.049)$. To summarize our results, using market-based measure of accounting conservatism do not support hypothesis 2. Moderating variable (BONUS*CGSTRENGTH) is negatively related with CON-BTM but the relation is not significant. 
Table 8. Regression of the moderating variable CGSTRENGTH on CON-ACC and CEO bonus compensation

\begin{tabular}{|c|c|c|c|c|c|c|c|c|c|c|}
\hline & \multirow[t]{2}{*}{ Expectations } & \multicolumn{3}{|c|}{ Model I } & \multicolumn{3}{|c|}{ Model II } & \multicolumn{3}{|c|}{ Model III } \\
\hline & & $\mathrm{B}$ & Beta & Sig. & $\mathrm{B}$ & Beta & Sig. & $\mathrm{B}$ & Beta & Sig. \\
\hline Intercept & $?$ & 0.291 & & $(0.015)^{*}$ & 0.360 & & $(0.004)^{* * * *}$ & & 0.348 & $(0.006)^{* * * *}$ \\
\hline BONUS & $(-)$ & & & & -0.005 & -0.018 & $(0.385)$ & -0.005 & -0.020 & $(0.339)$ \\
\hline CGSTRENGTH & $(+)$ & & & & 0.013 & -0.046 & $(0.034)^{* *}$ & 0.013 & -0.049 & $(0.027)^{* *}$ \\
\hline $\begin{array}{l}\text { BONUS* } \\
\text { CGSTRENGTH }\end{array}$ & $(+)$ & & & & & & & -0.004 & -0.019 & $(0.352)$ \\
\hline \multicolumn{11}{|l|}{ Control variables } \\
\hline $\mathrm{SIZE}$ & $(+/-)$ & -0.041 & -0.170 & $(0.000)^{* * *}$ & -0.044 & -0.183 & $(0.000)^{* * * *}$ & -0.043 & -0.181 & $(0.000)^{* * * *}$ \\
\hline SALESGROWTH & $(+)$ & 0.000 & -0.022 & $(0.289)$ & 0.000 & -0.014 & $(0.509)$ & 0.000 & -0.014 & $(0.523)$ \\
\hline $\mathrm{LEV}$ & $?$ & 0.443 & 0.248 & $(0.000)^{* * *}$ & 0.452 & 0.253 & $(0.000)^{* * * *}$ & 0.451 & 0.253 & $(0.000)^{* * * *}$ \\
\hline $\mathrm{ROA}$ & $(+)$ & 1.898 & 0.468 & $(0.000)^{* * *}$ & 1.889 & 0.466 & $(0.000)^{* * * *}$ & 1.895 & 0.468 & $(0.000)^{* * * *}$ \\
\hline LITIGATIONRISK & $(+)$ & 0.058 & 0.093 & $(0.000)^{* * *}$ & 0.057 & 0.091 & $(0.000)^{* * * *}$ & 0.057 & 0.092 & $(0.000)^{* * * *}$ \\
\hline $\mathrm{R}^{2}$ & & \multicolumn{3}{|c|}{0.296} & \multicolumn{3}{|c|}{0.299} & \multicolumn{3}{|c|}{0.299} \\
\hline
\end{tabular}

Hypothesis 2 examines the mitigating effect of strong corporate governance to the negative relation between CEO compensation and accounting conservatism resulting in higher degree of conservatism. Hypothesis 2 suggests a positive influence of corporate governance strength to accounting conservatism. To test this hypothesis we performed regressions using both the accrual-based measure and the market-based measure of accounting conservatism. Both measures have not significant relation with corporate governance strength. Accounting conservatism measured by the accrual-based measure is positively associated with conservatism yet the relation is insignificant. Accounting conservatism measured by the marketbased measure is negatively associated with conservatism but the relation is also insignificant. As a result, we reject hypothesis 2 .

\subsection{Additional analysis}

We perform robustness tests to our findings for hypotheses 1 and 2. Conservative reporting and CEO compensation vary across industries, which could have an impact on our results. Therefore we perform tests for industry-specific effects by estimating all variables as deviations from the industry mean (Ahmed et al., 2002). We do not use the dummy variable LITIGATIONRISK in our additional analysis. We classify industries according to their four-digit SIC codes. We perform within the variables industry classification. First, we calculate the mean industry for every industry in the variable. Then we estimate the variables which are adjusted for industry-effects by calculating the deviation from the industry mean. Ahmed et al. (2002) argue that variables that are adjusted for industry-specific effects improve the research concerning economic characteristics and GAAP-mandated conservatism.

The results of the additional analysis of hypothesis 1 are present in table 9 . Table 9 contains both the accrual-based measure for conservatism and the market-based measure. We show the regular results next to the industry-specific results to facilitate the comparison. $\mathrm{R}^{2}$ does not alter when using the accrual-based measure of conservatism. However, when we use the marketbased measure of conservatism there is a minor decrease in $\mathrm{R}^{2}$ (from $\mathrm{R}^{2}=.299$ to $\mathrm{R}^{2}=.265$ ).

The conclusions of the adjusted results are the same for the variables BONUS, SIZE, SALESGROWTH and ROA. We notice some changes in intercepts, $L E V$ and LITIGATIONRISK. The value of intercept for both measures reverses from positive to negative after the adjustments for industry-specific effects. Therefore, accounting conservatism is negative when the value of all independent variables is zero for both measures adjusted for industry-effects. The adjusted intercept with the accrual-based measure is significant at 0.01 level and under the market-based measure is not significant. 
Table 9. Additional analysis of accounting conservatism and CEO bonus compensation- Hypothesis 1

CON-ACC

CON-BTM

Findings Adj. for industry Findings Industry Adj.

$\begin{array}{lcccc}\text { nntercept } & 0.227 & -0.005 & 0.279 & -0.000 \\ & (0.000)^{* * *} & (0.000)^{* * *} & (0.021)^{* *} & (0.338) \\ \text { BONUS } & 0.002 & 0.002 & -0.006 & -0.004 \\ & (0.031)^{* *} & (0.048)^{* *} & (0.270) & (0.492)\end{array}$

\section{Control variables}

\begin{tabular}{|c|c|c|c|c|}
\hline $\mathrm{SIZE}$ & $\begin{array}{l}-0.008 \\
(0.000)^{* * *}\end{array}$ & $\begin{array}{l}-0.007 \\
(0.000)^{* * *}\end{array}$ & $\begin{array}{l}-0.040 \\
(0.000)^{* * *} *\end{array}$ & $\begin{array}{l}-0.034 \\
(0.000)^{* * *}\end{array}$ \\
\hline SALESGROWTH & $\begin{array}{l}0.000 \\
(0.046)^{* *}\end{array}$ & $\begin{array}{c}0.000 \\
(0.022)^{* *}\end{array}$ & $\begin{array}{l}0.000 \\
(0.289)\end{array}$ & $\begin{array}{c}0.000 \\
(0.592)\end{array}$ \\
\hline LEV & $\begin{array}{l}-0.010 \\
(0.162)\end{array}$ & $\begin{array}{l}-0.014 \\
(0.040) * *\end{array}$ & $\begin{array}{l}0.442 \\
(0.000)^{* * * *}\end{array}$ & $\begin{array}{l}0.455 \\
(0.000)^{* * * *}\end{array}$ \\
\hline ROA & $\begin{array}{l}-0.343 \\
(0.000)^{* * *}\end{array}$ & $\begin{array}{l}-0.338 \\
(0.000)^{* * *}\end{array}$ & $\begin{array}{l}1.895 \\
(0.000)^{* * *}\end{array}$ & $\begin{array}{l}1.792 \\
(0.000)^{* * *}\end{array}$ \\
\hline LITIGATIONRISK & $\begin{array}{l}0.020 \\
(0.000)^{* * *}\end{array}$ & $\begin{array}{l}0.019 \\
(0.000)^{* * * *}\end{array}$ & $\begin{array}{c}0.058 \\
(0.000)^{* * *}\end{array}$ & $\begin{array}{l}0.023 \\
(0.065)^{* *}\end{array}$ \\
\hline $\mathrm{R}^{2}$ & 0.243 & 0.243 & 0.297 & 0.263 \\
\hline
\end{tabular}

When we use the accrual-based measure, the result for leverage is negative and insignificant. However, this relation is reversed to significant at the 0.05 level with the use of industry-adjusted variables. The unstandardized coefficient of litigation risk decreases from .058 to .023 indicating that when we include industry-adjusted variables the relation between LITIGATIONRISK and CON-BTM is weaker. Furthermore, the significance level of this relation also dropped the 0.01 level to the 0.05 level. The results of the additional analysis are in line with the first test conducted for hypothesis 1 . The values of intercept, leverage and litigation risk have changed however there are not any changes in the variable for bonus. The results of industry-adjusted variables reject the first hypothesis as well.

Table 10 presents the results of additional analysis for hypothesis 2 . After controlling for industry-specific effects we get the same results for the variables BONUS, BONUS*CGSTRENGTH, SIZE and ROA. However, the values of intercepts have changed as they reversed to negative under both measures of conservatism. When we use the market-based measure for accounting conservatism the significance level of corporate governance strength is decreased (from 0.05 to 0.10 level). Furthermore, the significance level of litigation risk under the CON-BTM measure decreases from 0.01 to 0.10. When we use the accrual-based measure leverage and sales growth maintain the direction of the relation however their significance level is changed. For the variable SALESGROWTH the significance increases from 0.05 to 0.01 level. The significance level of leverage changes from the 0.10 level to the 0.05 . However, the additional analysis does not change the significance of the moderating variable BONUS*CGSTRENGTH to support hypothesis 2 . The findings of additional analysis are in line with our initial test for hypothesis 2 , so we reject $\mathrm{H} 2$. 
Table 10. Additional analysis of moderating effect of corporate governance strength- Hypothesis 2

CON-ACC

CON-BTM

\begin{tabular}{llccc} 
& \multicolumn{2}{c}{ Findings } & Adj. for industry & \multicolumn{2}{c}{ Findings Industry Adj. } \\
\hline Intercept & 0.210 & -0.005 & 0.348 & -0.000 \\
BONUS & $(0.000)^{* * *}$ & $(0.000)^{* * *}$ & $(0.006)^{* * *}$ & $(0.349)$ \\
& 0.002 & 0.002 & -0.005 & -0.003 \\
& $(0.055)^{*}$ & $(0.082)^{*}$ & $(0.339)$ & $(0.533)$ \\
CGSTRENGTH & -0.003 & -0.003 & & \\
& $(0.008)^{* * * *}$ & $(0.009)^{* * *}$ & 0.013 & 0.011 \\
& & & $(0.027)^{* *}$ & $(0.072)^{*}$ \\
BONUS* & 0.000 & 0.000 & -0.004 & -0.005 \\
CGSTRENGTH & $(0.573)$ & $(0.716)$ & $(0.352)$ & $(0.246)$
\end{tabular}

Control variables

\begin{tabular}{lllll} 
SIZE & -0.007 & -0.007 & -0.049 & -0.036 \\
& $(0.000)^{* * *}$ & $(0.000)^{* * *}$ & $(0.000)^{* * * *}$ & $(0.000)^{* * * *}$ \\
SALESGROWTH & & & & \\
& 0.000 & 0.000 & 0.000 & 0.000 \\
LEV & $(0.014)^{* *}$ & $(0.007)^{* * *}$ & $(0.523)$ & $(0.837)$ \\
& -0.012 & -0.016 & 0.451 & 0.462 \\
ROA & $(0.089)^{*}$ & $(0.019)^{* *}$ & $(0.000)^{* * *}$ & $(0.000)^{* * *}$ \\
& -0.342 & -0.338 & 1.895 & 1.798 \\
LITIGATIONRISK & $(0.000)^{* * *}$ & $(0.000)^{* * *}$ & $(0.000)^{* * *}$ & $(0.000)^{* * *}$ \\
& 0.020 & 0.019 & 0.057 & 0.023 \\
\hline $\mathrm{R}^{2}$ & $(0.000)^{* * *}$ & $(0.000)^{* * *}$ & $(0.000)^{* * *}$ & $(0.071)^{*}$ \\
\hline$*$ /****** & 0.246 & 0.246 & 0.299 & 0.265 \\
\hline
\end{tabular}

To summarize the results of our additional analysis after controlling for industry-specific effects we conclude that our hypotheses are rejected. The regressions with industry-adjusted variables result in a reverse in intercept values from positive to negative. We also notice changes in the significance level of several independent variables. There is a slight deviation of unstandardized coefficients of some variables from the first regression. Even though we maintain our conclusions for the hypotheses of our study, the results are not entirely robust in another setting.

\section{Conclusions, limitations and recommendations}

The recent economic crisis, scandals and corporate failures like these of Enron and WorldCom drew global attention to the implementation of corporate governance. Corporate governance mechanisms aim to monitor management's behavior, protect the interests of shareholders and diminish agency problems. Prior literature argues that strong corporate governance has a moderating effect on agency problems. However, there are conflicts about effectiveness and efficiency of current corporate governance systems. A worldwide concern is expressed about corporate governance (Khanchel, 2007).

The purpose of this paper is to examine the mitigating impact of corporate governance strength on the agency problem. The form of the agency problem that we investigate is the relation between CEO bonus compensation and conservative accounting. Our sample contains S\&P 500 firms for the years 2008-2013 to analyze the impact of strong corporate governance on the association between $\mathrm{CEO}$ bonus compensation and accounting conservatism. We use two proxies to measure accounting conservatism: the accrual-based measure and the market-based measure. First, we examine the relation between CEO bonus compensation and accounting conservatism. Taking into account the agency theory and the managerial self-interest theory a negative relation is expected. Information asymmetry in a company enables managers to make decisions for their own interest. Therefore, managers prefer to over value net income or net assets and make decisions that include more risk to receive higher bonus. However, our results do not indicate that CEO bonus compensation and accounting conservatism related negatively. Furthermore, our findings do not imply a significant relation. In contrast, when we use the accrual-based measure for accounting conservatism we find a significant yet positive relation between CEO bonus compensation and accounting conservatism. The use of market-based measure for accounting conservatism indicates a negative but insignificant relation 
between CEO bonus compensation and accounting conservatism. Our findings are not in line with the managerial self-interest theory and the agency theory.

Subsequently, we examine the influence of corporate governance strength on the relation between CEO bonus compensation and accounting conservatism. A positive moderating impact of corporate governance strength on the relation between CEO bonus compensation and accounting conservatism was expected. However, our results are not in line with the existing literature and do not provide evidence to support this hypothesis. Our findings based on the accrual-based measure for conservatism suggest an insignificant positive relation while the results under the market-based measure suggest an insignificant negative relation. The results under both measures are insignificant indicating that we cannot a find a strong evidence for the moderating effect of corporate governance strength on the agency problem.

We further test the robustness of our results in another setting by performing additional analysis. We adjust all the variables to control for industry-specific effects. The results of additional analysis provided negative intercept values and changes in the significance level of independent variables. We conclude that our results are not absolutely robust in another setting, however additional analysis provides the same conclusions.

A limitation of this paper is that we do not find evidence supporting the hypothesis that strong corporate governance can moderate the negative relation between CEO compensation and accounting conservatism. Our results provide insignificant relation of contradictory direction, as a result we cannot make conclusions regarding the moderating effect of strong corporate governance. Another limitation of this paper is that the findings cannot be generalized through settings with smaller (national) companies. We measure corporate governance strength by obtaining data from the Thomson Reuters ASSET4 ESG database which provides scores for large international firms. Future research may provide solutions and overcome these limitations. Future studies could also focus on corporate governance mechanisms before and after the implementation of the SarbanesOxley Act in 2002. Future research could examine the improvement of the financial reporting quality and consequently the quality of corporate governance.

\section{References}

Agrawal, A., and Chadha, S. (2005). Corporate Governance and Accounting Scandals. Journal of Law and Economics. 48(2): $371-406$. Ahmed, S., Billings, B.K., Morton, R.M., and Stanford-Harris, M. (2002). The Role of Accounting Conservatism in Mitigating Bondholder-Shareholder Conflicts over Dividend Policy and in Reducing Debt Costs. The Accounting Review. 77(4): 867-890.

Bachmann, L., R., Loyeung, A., Matolcsy, P., Z. and Spiropoulos, H. (2019). Powerful CEOs, cash bonus contracts and firm performance. Journal of Business Finance and Accounting. 47(1-2): 100-131.

Ball, R., Kothari, S.P., and Robin, A. (2000). The effect of international institutional factors on properties of accounting earnings. Journal of Accounting and Economics. 29: 1-51.

Ball, R., and Shivakumar, L. (2005). Earnings quality in UK private firms: comparative loss recognition timeliness. Journal of Accounting and Economics. 39: 83-128.

Basu, S. (1997). The conservatism principle and the asymmetric timeliness of earnings. Journal of Accounting E゚ Economics. $24: 3-37$.

Beaver, W.H., and Ryan, S.G. (2000). Chicago Biases and Lags in Book Value and Their Effects on the Ability of the Book-toMarket Ratio to Predict Book Return on Equity. Journal of Accounting Research. 38(1): 127-148.

Bebchuk, L.A., and Fried, J.M. (2003). Executive compensation as an agency problem. Journal of Economic Perspectives. 17(3): 71-92.

Berry, T.K., Fields, L.P., and Wilkins, M.S. (2006). The interaction among multiple governance mechanisms in young newly public firms. Journal of Corporate Finance. 12: 449- 466.

Bhojray, S., and Sengupta, P. (2003). Effect of Corporate Governance on Bond Ratings and Yields: The Role of Institutional Investors and Outside Directors. Journal of Business. 76(3): 455-475.

Bissessur, S.W. (2008). Earnings quality and earnings management: the role of accounting accruals (academic thesis). University of Amsterdam, Amsterdam, The Netherlands

Brick, I.E., Palmon, O., and Wald, J.K. (2006). CEO compensation, director compensation, and firm performance: Evidence of cronyism? Journal of Corporate Finance. 12: 403-423.

Bris, A., and Cantale, S. (2004). Bank capital requirements and managerial self-interest. The Quarterly Review of Economics and Finance. 44: 77-101.

Bushman, R.M., Indjejikian, R.J., and Smith, A. (1996). CEO compensation: The role of individual performance evaluation. Journal of Accounting and Economics. 21: 161-193

Bushman, R.M., and Piotroski, J.D. (2006). Financial reporting incentives for conservative accounting: The influence of legal and political institutions. Journal of Accounting and Economics. 42: 107-148.

Cohen, D.A., Dey, A., and Lys, T.Z. (2004). The Sarbanes Oxley Act of 2002: Implications for Compensation Structure and Risk-Taking Incentives of CEOs (Working paper). Retrieved from: http://leeds-faculty.colorado.edu/bhagat/SOX-CEO-Compensation$\underline{\text { Investment.pdf }}$

Core, J.E., Holthausen, R.W., and Larcker, D.F. (1999). Corporate governance, chief executive officer compensation, and firm performance. Journal of Financial Economics. 51: 371-406.

Dechow, P.M., and Ge, W. (2006). The persistence of earnings and cash flows and the role of special items: Implications for the accrual anomaly. Review of Accounting Studies. 11(2): 253-296.

Denis, D.J., Hanouna, P., and Sarin, A. (2006). Is there a dark side to incentive compensation? Journal of Corporate Finance. 12: 467488. 
Fan, J.P.H., and Wong, T.J. (2002). Corporate ownership structure and the informativeness of accounting earnings in East Asia. Journal of Accounting and Economics. 33: 401-425.

Field, A. (2000). Discovering Statistics Using SPSS. London: SAGE Publications Ltd.

Francis, B., Hasan, I., Park, J.C., and Wu, Q. (2009). Gender Differences in Financial Reporting Decision Making: Evidence from Accounting Conservatism (Working paper). Retrieved from the Social Science Research Network: http://papers.ssrn.com/sol3/papers.cfm?abstract_id=1471059

Gillan, S.L. (2006). Recent Developments in Corporate Governance: An Overview. Journal of Corporate Finance. 12: $381-402$.

Givoly, D., and Hayn, C. (2000). The changing time-series properties of earnings, cash flows and accruals: Has financial reporting become more conservative? Journal

Guay, W., and Verrecchia, R. (2006). Discussion of an economic framework for conservative accounting and Bushman and Piotroski (2006). Journal of Accounting and Economics. 42: 149-165.

Guth, W.D., and MacMillan, I.C. (1986). Strategy Implementation Versus Middle Management Self-Interest. Strategic Management Journal. 7(4): 313-327.

Healy, P.M. (1985). The effect of bonus schemes on accounting decisions. Journal of Accounting and Economics. 7: 85-107.

Hsu, C., Novoselov, E., K., and Wang, R. (2017). Does accounting conservatism mitigate the shortcomings of CEO overconfidence? The Accounting Review. 92(6): 77-101.

Ioannou, I., and Serafeim, G. (2010). What Drives Corporate Social Performance? International Evidence from Social, Environmental and Governance Scores (working paper). Retrieved from: http://www.hbs.edu/faculty/Publication\%20Files/11-016.pdf

Jensen, M.C., and Meckling, W.H. (1976). Theory of the firm: Managerial behavior, agency costs and ownership structure. Journal of Financial Economics. 3: 305-360.

Kamalanabhan, T.J. and Sunder, D.L. (1999). Managerial risk-taking: An empirical study. Social Behavior and Personality: an international journal. 27(4): 42 1-429.

Khan, M., and Watts, R.L. (2009). Estimation and empirical properties of a firm-year measure of accounting conservatism. Journal of Accounting and Economics. 48: 132-150.

Khanchel, I. (2007). Corporate governance: measurement and determinant analysis. Managerial Auditing Journal. 22(8): 740-760.

Kirkpatrick, G. (2009). The corporate governance lessons from the financial crisis. OECD Journal: Financial Market Trends. 2009(1): 61-87.

Klapper, L.F., and Love, I. (2004). Corporate governance, investor protection, and performance in emerging markets. Journal of Corporate Finance. 10: 703-728.

Larcker, D., and Tayan, B. (2011). Corporate Governance Matters. United States of America: Pearson Education.

Leventis, S., Dimitropoulos, P., and Owusu-Ansah, S. (2013). Corporate Governance and Accounting Conservatism: Evidence from the Banking Industry. Corporate Governance: An International Review. $21(3)$ : 264-286.

Luo, Y., and Salterio, S.E. (2014). Governance Quality in a "Comply or Explain" Governance Disclosure Regime. Corporate Governance: An International Review. 22(6): 460-481.

March, J.G., and Shapira, Z. (1987). Managerial Perspectives on Risk and Risk Taking. Management Science. 33(11): $1404-1418$.

Matsumura, E.M., and Shin, J.Y. (2005). Corporate Governance Reform and CEO Compensation: Intended and Unintended Consequences. Journal of Business Ethics. 62: 101-113.

Murphy, K.J. (1985). Corporate performance and managerial remuneration. Journal of Accounting and Economics. 7: 11-42.

Rappaport, A. (2005). The economics of short-term performance obsession. Financial Analysts Journal. 61(3): 65-79.

Rees, W., and Rodionova, T. (2015). The Influence of Family Ownership on Corporate Social Responsibility: An International Analysis of Publicly Listed Companies. Corporate Governance: An International Review. 23(3): 184-202.

Renders, A., and Gaeremynck, A. (2012). Corporate Governance, Principal-Principal Agency Conflicts, and Firm Value in European Listed Companies. Corporate Governance: An International Review. 20(2): 125-143.

Porta, R.L., Lopez-de-Silanes, F., Shleifer, A., and Vishny, R. (2000). Investor protection and corporate governance. Journal of Financial Economics. 58: 3-27.

Sanders, W.M.G., and Carpenter, M.A. (1998). Internationalization and Firm Governance: The Roles of CEO Compensation, Top Team Composition, and Board Structure. The Academy of Management Journal. 41(2): 158-178.

Saunders, M., Lewis, P., and Thornhill, A. (2009). Research Methods for Business Students. England: Prentince Hall.

Shalev, R., Zhang, I.X., and Zhang, Y. (2013). CEO Compensation and Fair Value Accounting: Evidence from Purchase Price Allocation. Journal of Accounting Research. 51 (4): 819-854.

Shleifer, A., and Vishny, R.W. (1997). A Survey of Corporate Governance. The Journal of Finance. 52(2): 737-783.

Smirnova, S., A., and Zavertiaeva, A., M. (2017). Which came first, CEO compensation or firm performance? The causality dilemma in European companies. Research in International Business and Finance. 42: 658-673.

Smith, C.W., and Watts, R.L. (1992). The investment opportunity set and corporate financing, dividend, and compensation policies. Journal of Financial Economics. 32: 263-192.

Tuschke, A., and Sanders, W.M.G. (2003). Antecedents and Consequences of Corporate Governance Reform: The Case of Germany. Strategic Management Journal. 24(7): 631-649.

Watts, R.L. (2003). Conservatism in Accounting Part I: Explanations and Implications. Accounting Horizons. 17(3): $207-221$.

Watts, R.L., and Zimmerman, J.L. (1978). Towards a Positive Theory of the Determination of Accounting Standards. The Accounting Review. 53(1): 112-134.

Zmijewski, M.E., and Hagerman, R.L. (1981). An income strategy approach to the positive theory of accounting standard setting/choice. Journal of Accounting and Economics. 3: 129-149.

This is an Open Access article distributed under the terms of the Creative Commons Attribution Licence

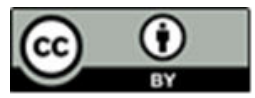

